Clinical and cytological study of the oral mucosa of smoking and non-smoking qat chewers in Yemen

\author{
Dissertation \\ zur Erlangung des akademischen Grads \\ Dr. med. dent.
}

an der Medizinischen Fakultät

der Universität Leipzig

eingereicht von:

Mohammed Hijazi

geb. 09.02.1971

angefertigt an:

Universitätsklinikum Leipzig AöR

Department für Kopf- und Zahnmedizin

Poliklinik für Zahnerhaltung und Parodontologie

Funktionsbereich Parodontologie

Liebigstr. 12, Haus 1

04103 Leipzig

Betreuer:

Univ.-Prof. Dr. med. habil. Dr. h.c. Holger Jentsch

Univ.-Prof. Dr. med. dent. habil. Torsten W. Remmerbach

Beschluss über die Verleihung des Doktorgrades Vom 20.Juni 2017 


\section{Inhaltsverzeichnis}

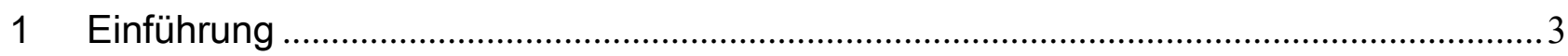

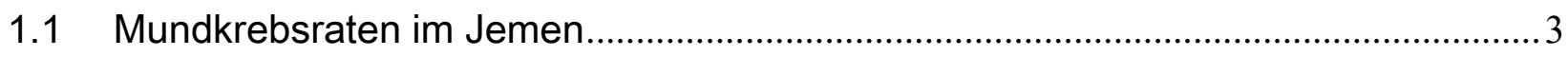

1.2 Qat, Qat-Konsum, mit Qat-Kauen verbundene Gebräuche...................................4

1.3 Die Folgen von Qat-Konsum für die Mundschleimhaut.........................................4

1.4 Die Bürstenbiopsie als adjuvante diagnostische Methode ...................................... 7

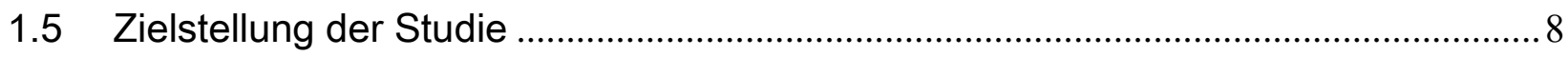

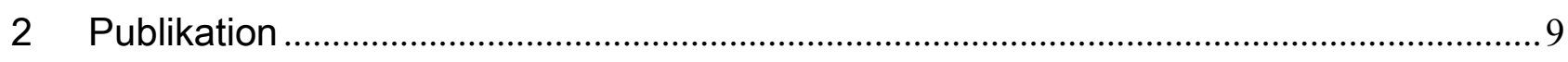

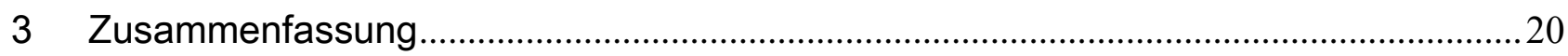

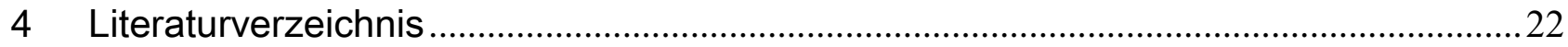

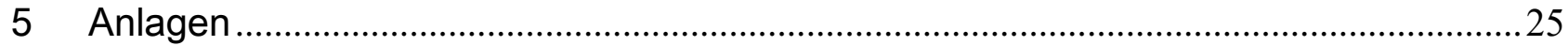

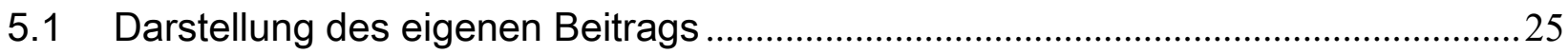

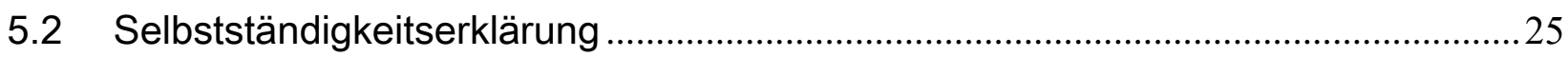

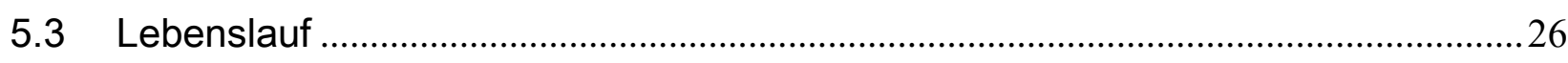

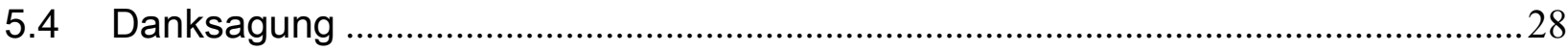




\section{Einführung}

\subsection{Mundkrebsraten im Jemen}

Der Jemen hat eine der höchsten Alters-standardisierten Mortalitätsraten für Krebs der Lippe oder der Mundhöhle weltweit. Basierend auf Daten aus dem Jahr 2008, die von der GLOBOCAN Datenbank der Internationalen Agentur für Krebsforschung (International Agency for Research on Cancer (IARC)) veröffentlicht wurden, rangierte der Jemen mit einer Mortalität von 2,4 pro 100.000 Einwohner auf dem 28. Platz von 184 Nationen, Männer lagen auf dem 54. Platz und Frauen auf dem 11. Platz, siehe hierzu Abbildung 1 [1]. Interessanterweise lagen die Mortalitätsraten bei beiden Geschlechtern mit 2,42 pro 100.000 Einwohner bei den Männern bzw. 2,40 pro 100.000 Einwohner bei Frauen in einem ähnlichen Bereich. Zum Vergleich dazu lagen Männer in Deutschland auf Rang 64, Frauen auf Rang 109, der Unterschied in der Mortalität war mit 2,04 bei den Männern und 0,6 bei den Frauen beträchtlich.

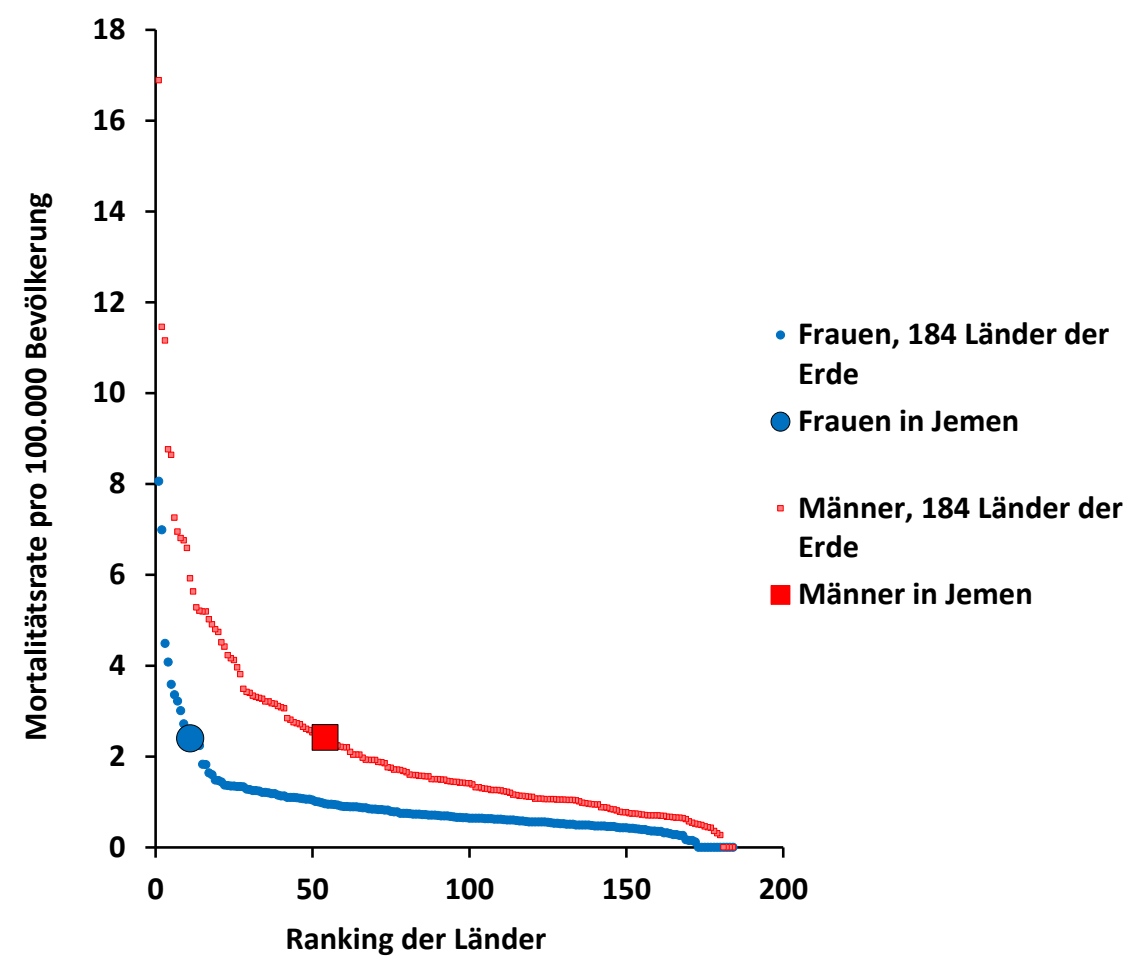

Abbildung 1: Mortalität durch Krebs der Lippe oder der Mundhöhle in 184 Ländern der Erde und Jemen im Besonderen; International Agency for Cancer Research (IARC), GLOBOSCAN Datenbank 2008. 
Die Gründe für diese hohen Mortalitätsraten sind kaum erforscht. Eine der häufig genannten Hypothesen benennt den unter Jemeniten hohen Konsum von Blättern der Pflanze Qat.

\subsection{Qat, Qat-Konsum, mit Qat-Kauen verbundene Gebräuche}

Qat ist der Name für Blätter der Pflanze Catha edulis (Abbildung 2, links). Diese Pflanze gehört zur Familie der Celastraceae. Qat kennt man auch als Catha edulis Forsk. Qat-Blätter enthalten mehr als 40 Alkaloide, Glycoside, Tannine, Terpenoide und andere Verbindungen. Cathin und Cathinon sind die wichtigsten Alkaloide der Qat-Blätter, die einen Amphetaminartigen Effekt entfalten [2]. Daher ruft Qat psychologische Effekte hervor, wie z.B. Euphorie und Erregung [3]. Üblicherweise wird Qat so konsumiert, dass Blätter in eine Wangentasche gesteckt werden und einige Stunden gekaut werden [4].

In dieser geographischen Region, wie z. B. im Jemen, in Äthiopien und Somalia, kauen Millionen von Männern und Frauen Qat, häufig am Nachmittag und im Rahmen von verschiedenen speziellen sozialen Zusammenkünften, viele kauen Qat auch während der Arbeit. Die Statistiken bezüglich der Frage der Häufigkeit, Qat pro Woche zu kauen, zeigt, dass es dabei offenbar zwei Gruppen gibt: viele Personen kauen Qat einmal pro Woche, andere kauen Qat quasi jeden Tag [2].

\subsection{Die Folgen von Qat-Konsum für die Mundschleimhaut}

Tierexperimente bei Mäusen, die in den frühen 1990er Jahren durchgeführt worden waren, hatten ergeben, dass ein Extrakt aus der Qat-Pflanze in einer Dosis-Wirkungs-Beziehung sowohl das Körpergewicht als auch die Mortalität beeinflussen [5]. Frühe humanepidemiologische Studien hingegen folgerten, dass der Konsum von Qat nicht signifikant mit oralen Leukoplakien [6] assoziiert war und auch keine größeren Effekte auf die Mundhöhle hatte [7]. Danach wurden jedoch Studien veröffentlicht, die angaben, dass das Kauen von Qat einen negativen Effekt auf die Mundgesundheit haben könnte, zum Beispiel in Form von Zahnverlust [8], Parodontitis [9] und sichtbare (weiße) Veränderungen in der Mundschleimhaut [2], [8], [10]. Histopathologische Studien berichteten über das Vorkommen von Dysplasien, d.h. abnormales, epitheliales Zellwachstum, welches durch ein 
Spektrum von zytologischen, den Reifegrad verändernden und „architektonischen“ Charakteristika gekennzeichnet ist [3].

Vergleichende Studien bei Personen, die Qat kauen und solchen, die nicht Qat konsumierten, fanden heraus, dass Qat-kauende Personen eine höhere Prävalenz von weißen Läsionen oder Atypien haben [2], [10], [11]. Zwischen 22\% und 83\% der Qatkauenden Personen hatten weiße Läsionen, aber nur 1\% bzw. 16\% von Personen, die Qat nicht kauten [2], [10].

Weil einige Qat-Konsumenten die Blätter vorzugsweise auf einer Seite des Mundes kauen, kann der Einfluss von Qat auf die Schleimhaut des Mundes auch durch den Vergleich der Kauseite mit der kontralateralen Seite untersucht werden. Ali et al. hatten dazu (2006 und 2007) die Ergebnisse zweier Studien veröffentlicht. In der ersten fanden sie milde, epitheliale Dysplasien in 25\% der Kauseiten, aber nie auf der kontralateralen Seite [4]. In der zweiten Studie identifizierten die Autoren Dysplasien in 9\% der Mundschleimhaut auf der Kauseite bei nicht-rauchenden Qat-Konsumenten, und wiederum keine auf der Seite des Mundes, auf der nicht Qat-Blätter gekaut wurde [3]. Allerdings wurden bis dato keine Studien veröffentlicht, die separat die Häufigkeit von Läsionen oder zytologischen Veränderungen auf der bukkalen bzw. gingivalen Region auf der Kau- bzw. kontralateralen Seite untersuchten.

Prinzipiell unterliegen epidemiologische, beobachtende Studien immer der Gefahr von Verzerrungen. Im Kontext der vorliegenden Thematik ist es daher von großer Bedeutung, den Effekt von Qat von anderen, potentiell die Mundschleimhaut schädigenden Gewohnheiten, wie z.B. das Rauchen von Zigaretten oder von Wasserpfeifen (mada'a), Tabakkauen (shamma), Betelnuss-Kauen (tumbol) oder Alkohol [9], [12] zu trennen. Nikotin (Zigarettenrauchen) und Alkohol sind zwei Noxen, für die die Assoziation mit Mundhöhlenkrebs gut dokumentiert ist [13], aber auch die Benutzung von Wasserpfeifen und das Tabakkauen wurden mit Mundhöhlenkrebs in Verbindung gebracht [14], [15]. Während Gorsky et al. (2004) keine statistisch signifikante Assoziation zwischen Zigarettenrauchen und dem Vorkommen von weißen Läsionen finden konnte [10], beobachtete Ali et al. (2007) bei 36\% einer Gruppe rauchender Qat-Konsumenten in der Mundschleimhaut weiße Läsionen, aber nur bei $9 \%$ in der Gruppe nicht-rauchender Qat- 
Konsumenten [3]. Allerdings war bei dieser Studie mit nur jeweils 11 untersuchten Personen in jeder Gruppe die Stichprobengröße zu klein, um einen statistisch signifikanten Effekt nachweisen zu können. In der genannten Studie wurde auch noch eine dritte Gruppe von 11 Wasserpfeife rauchenden Personen untersucht. In dieser war die Dysplasie-Rate mit 45\% ähnlich hoch wie bei Rauchern [3]. Um die verschiedenen Gewohnheiten, die alle auf die Mundschleimhaut einen schädigenden Einfluss haben können, voneinander zu unterscheiden, ist es für Beobachtungsstudien notwendig, diese durch eine sorgfältige Kombination aus Restriktion und Stratifikation zu planen. Bestimmte beeinflussende Faktoren können so eliminiert werden, dass sie grundsätzlich für die gesamte Studienpopulation ausgeschlossen werden, z.B. könnten Personen, die Tabak kauen, grundsätzlich a priori aus der Studie ausgeschlossen werden (Restriktion). Und um den Effekt von Rauchen von dem des Qat-Kauens zu trennen, ist es sinnvoll, eine Gruppe mit rauchenden Qat-kauenden Personen separat von einer Gruppe nicht-rauchender Qatkauender Personen zu rekrutieren (Stratifikation). 


\subsection{Die Bürstenbiopsie als adjuvante diagnostische Methode}

Erste Versuche, potentiell maligne Läsionen der Mundschleimhaut mittels zytologischen Methoden zu erfassen, reichen bis in die 2. Hälfte des 19. Jahrhunderts zurück [16]. Mitte des 20. Jahrhunderts gelang Papanicolaou mit seinen Arbeiten ein großer Fortschritt im Bereich der gynäkologischen Malignomdiagnostik der Cervix uteri [17]. In den 1950er und 1960er Jahren wurden eine Reihe von Arbeiten veröffentlicht, die versuchten, dieses in der Gynäkologie so erfolgreiche Prinzip, diagnostisch oder im Rahmen von einer Vorsorgeuntersuchung, für die Erkennung epithelialer Tumoren in der Mundhöhle zu übertragen [18], [19], [20]. Dies gelang aber nur bedingt, u.a. weil die in der Cervix uteri zu findende Transformationszone, in der atypische Zellen frühzeitig an die Oberfläche gelangen, in der Mundschleimhaut fehlen und eine Gewinnung tiefer Zellschichten des Plattenepithels ohne speziellen instrumentellen Aufwand nicht möglich war [16]. Mitte der 1980er Jahre wurde die Verwendung von Nylon-Bürsten nicht nur in der Gynäkologie etabliert, sondern bestätigte sich auch als ein einfaches, nicht-invasives Instrument zur Gewinnung oraler Epithelzellen [16]. Vorteile waren die verbesserte Qualität und Handhabbarkeit. Im Vergleich zur Histopathologie (als dem Goldstandard) wird die Sensitivität der oralen Bürstenbiopsie mit $79 \%$ bis $97 \%$ angegeben und die Spezifität mit 95,1\% bis 99,5\% [21], [22], [23], [24], [25]. Daher sollte die orale Bürstenbiopsie auch in der vorliegenden Studie zur Anwendung kommen.

Bezogen auf die durch Qat verursachten Schleimhautveränderungen fehlen Untersuchungen zur "Interobserver-Reliabilität" zwischen der technikfreien Inspektion mit dem menschlichen Auge bzw. der haptischen Palpation und der Bürstenbiopsie bei Qatkauenden Personen. Es ist prinzipiell möglich, dass zytologische Veränderungen mittels Bürstenbiopsie nachweisbar sind, bei denen eine Läsion dem Auge oder den tastenden Fingerspitzen entgehen, aber auch, dass eine Änderung visuell sichtbar ist, jedoch ein zytologisches Korrelat fehlt. Ein solcher Vergleich zwischen diesen beiden Methoden ist gerade in einer Population von Interesse und besonders aussagekräftig, bei denen weiße Läsionen in besonders hoher Häufigkeit zu erwarten sind. 


\subsection{Zielstellung der Studie}

Die Studie hatte die Zielstellung,

(1) die Häufigkeit visuell sichtbarer Läsionen und zytologischer Veränderungen bei nichtrauchenden Qat-konsumierenden Personen in den folgenden vier Regionen des Mundes zu bestimmen: bukkale und gingivale Region der Kauseite sowie der kontralateralen Seite;

(2) die Häufigkeit visuell sichtbarer Läsionen und zytologischer Veränderungen bei rauchenden Qat-konsumierenden Personen in den gleichen vier Regionen wie in (1);

(3) die Ergebnisse zu vergleichen (a) zwischen der Kauseite mit denen der kontralateralen Seite und (b) zwischen Rauchern und Nicht-Rauchern;

(4) den Grad der Übereinstimmung zwischen visueller Inspektion und Zytologie zu bestimmen. 


\section{Publikation}

Titel

Clinical and cytological study of the oral mucosa of smoking and nonsmoking qat chewers in Yemen

\section{Autoren}

Hijazi M, Jentsch H, Al-Sanabani J, Tawfik M, Remmerbach TW 


\title{
Clinical and cytological study of the oral mucosa of smoking and non-smoking qat chewers in Yemen
}

\author{
M. Hijazi ${ }^{1}$ - H. Jentsch ${ }^{1}$ - J. Al-Sanabani ${ }^{2}$ - M. Tawfik ${ }^{3}$ - T. W. Remmerbach ${ }^{4}$
}

Received: 5 June 2015 /Accepted: 13 August 2015

(C) Springer-Verlag Berlin Heidelberg 2015

\begin{abstract}
Objective The study was conducted to investigate the role of qat and smoking habits on the prevalence of visible and cytological abnormalities in the oral mucosa among Yemenites. Methods We recruited 30 non-smoking and 30 smoking Yemenites chewing qat unilaterally for at least 5 years. We inspected oral cavities for the presence of lesions and took brush biopsies from the buccal mucosa/gingiva of the chewing/non-chewing region.

Results All visible oral lesions were flat and homogeneous, and cytological changes were detected frequently. Among both non-smokers and smokers, white lesions and cytological changes were detected in $77 \%$ of all cases. On the chewing area, the proportion with white lesions ranged-depending on anatomical area and smoking status - between 47 and $93 \%$ and was significantly more frequent than on the non-chewing side (range 3-47\%). The proportion of regions with changes was similar in non-smokers and smokers. Kappa statistics for "interobserver" agreement between visual inspection and cytological specimens of brush biopsies was at best fair $(\leq 0.25)$
\end{abstract}

M. Hijazi and H. Jentsch contributed equally to the manuscript.

T. W. Remmerbach

torsten remmerbach@medizin uni-leipzig.de

1 Centre for Periodontology, Department of Cariology, Endodontology and Periodontology, University of Leipzig, Leipzig, Germany

2 Department of Oral Medicine, Faculty of Dentistry, University of Thamar, Thamar, Republic of Yemen

3 Joint Practice for Pathology, IPO Institute for Pathology, Berlin, Germany

4 Section of Oral Medicine, Department of Head Medicine and Oral Health, Leipzig University Hospital, Liebigstraße 10-14, 04103 Leipzig, Germany
Conclusions The high prevalence of visible lesions and cytological abnormalities among qat chewers was independent of smoking status.

Clinical relevance The moderate level of agreement between visual inspection and exfoliative cytology demonstrates the still challenging clinical management of chronic qat chewers, though brush biopsies including adjuvant techniques like DNA cytometry may support the clinical decision-making process in future.

\section{Keywords Oral white lesions · Qat $\cdot$ Smoking}

\section{Introduction}

Chewing of qat leaves (Catha edulis) is common in certain countries of East Africa, such as Ethiopia, Kenya, Somalia, and Djibouti, and it is particularly common in Yemen $[1,2]$.

Yemen has one of the highest age-standardized mortality rates for cancer of the lip or oral cavity in the world. Based on the 2008 data published by the GLOBOCAN database of the International Agency for Research on Cancer (LARC), Yemen ranks at number 28 of 184 countries, and for females even at 11th place [3]. The highly prevalent habit of chewing qat is one of the possible causes for the high oral cancer mortality in Yemen. Qat leaves contain alkaloids, tannis, terpenoids, and other compounds [4]. Cathine and cathinone are the most important alkaloid constituents of qat that have an amphetamine-like effect $[1,5]$. Chewing qat induces psychological effects, such as euphoria and excitement [2]. Consuming qat includes storing (takhzeen) of leaves in the vestibule of the mouth for a few hours as well as chewing the leaves [2].

While animal experiments on mice conducted in the early 1990s of the last century indicated that qat extract has a dosedependent effect on body weight and mortality [6], early 
epidemiological studies in humans concluded that qat was not significantly associated with oral leukoplakia [7] and had no particularly detrimental oral effects [8]. Thereafter, studies were published which indicated that qat chewing may have adverse effects on oral health, for example, attachment loss of teeth [9], periodontitis [10], and visible (white) changes of the oral mucosa $[1,9,11]$. Histopathological studies reported the occurrence of dysplasias (abnormal epithelial growth characterized by a spectrum of cytologic, maturational, and architectural changes) [12]. Qat chewers were compared to nonchewers and were found to have a higher prevalence of white lesions or atypias $[1,11,13]$. Between 22 and $83 \%$ of chewers were reported to have white lesions but only between 1 and $16 \%$ of non-chewers $[1,11]$.

Due to the fact that some of the qat chewers chew the leaves preferentially on one side of the mouth, the impact of qat effects on the oral mucosa may be investigated by comparing the chewing side with the non-chewing side. Ali et al. have conducted two studies in that respect: In the first study, they found mild epithelial dysplasias in $25 \%$ on the chewing side, but none on the non-chewing side [2]. In the second study, they identified dysplasias in $9 \%$ of the oral mucosa on the chewing side among non-smoking chewers and again none on the non-chewing side [12]. However, to date, no published studies have reported the comparative frequency of lesions or cytological changes on the buccal and gingival side of the chewing and non-chewing side separately.

In the spectrum of studies that needs to be done to better understand the possible influence of qat on the development of oral cancer, it is important to separate the effects of qat from other potentially carcinoma-inducing habits, such as smoking, water pipe use (mada'a), chewing tobacco (shamma), betel nut (tumbol), and alcohol $[10,14]$. Smoking and alcohol consumption are well-documented habits which may induce oral cancer [15]; in addition, water pipe and smokeless to bacco use also have been linked to oral cancer $[16,17]$. While Gorsky et al. reported no statistically significant association between the occurrences of white lesions and smoking [11], Ali et al. observed $36 \%$ white lesions in the oral mucosa on the chewing side among smokers, but only $9 \%$ among nonsmokers [12]. The statistical power to detect a real difference in the latter study was low due to the few number of included participants $(n=11)$. Many Yemenites use water pipes; however, alcohol consumption should be neglected as the case in most Muslim societies. In the study by Ali et al., a third group was investigated on 11 qat-chewing pipe users. It was found that the dysplasia rate on the chewing side (45\%) was similar to that among the qat-chewing smokers [12]. To "isolate" cancer risks incurred through the influence of qat or smoking, respectively, it is necessary to investigate the effects of qat and smoking in a stratified design.

The use of a nylon brush as a simple, non-invasive tool to collect cell samples from the oral epithelium has led to a renaissance of oral cytology [18]. In comparison to histopathology as the gold standard, the sensitivity of oral brush biopsies ranged from 79 to $97 \%$, while the specificity ranged from 95.1 to $99.5 \%$ [19-23]. However, to our knowledge, no scientific paper has compared the "interobserver" agreement between the two diagnostic methods brush biopsies (exfoliative cytology) and visual inspection in qat users. For example, while cytological changes may be present at regions where no lesion is visible, it may be also possible that visible lesions are detected without any substantiated cytological change. So, in this research, both clinical and cytological examinations have been investigated.

This study was conducted with the following objectives:

1. To measure the frequency of visible lesions and cytological changes among non-smoking Yemenite qat chewers in the following four areas: buccal and gingival part of the chewing region and gingival and buccal part of the nonchewing region

2. To measure the frequency of visible lesions and cytological changes among smoking Yemenite qat chewers in the same four areas as in (1)

3. To compare findings between chewing region and nonchewing region as well as between non-smokers and smokers

4. To assess the degree of agreement of visible inspection and cytology

\section{Materials and methods}

\section{Recruitment of participants}

This clinical study was approved by the ethics committees of the University of Leipzig (ref no. 241.11-11072011) and the University of Thamar in Yemen assuring compliance with the standards laid down in the ethical principles for medical research involving human subjects as formulated in the Declaration of Helsinki [24].

The study was performed at the outpatient clinic of the University of Thamar, Republic of Yemen, between February and March 2012. We recruited 30 non-smoking, but qatchewing participants and 30 smoking and qat-chewing patients. Participants had to be healthy adults who presented to the dental clinic for routine dental procedures unrelated to qatchewing habits such as operative, prosthetic procedures, or surgical extractions. To be included in the study, participants had to be chewers for at least 5 years, 3 days per week, and $3 \mathrm{~h}$ a day. In addition, all patients had to chew qat only on one side of the mouth; individuals who had the habit to chew qat on both sides were excluded. Shamma (smokeless tobacco), mada'a (water pipe), and tumbol (betel nut) users were also 
excluded Volunteers were handed out an informational leaflet giving general information about the study, including data protection issues. Patients willing to participate signed a written consent form

\section{Clinical examination}

The clinical examination was carried out using two disposable dental mirrots with the patient positioned on a dental chait. The ex amination of the oral mucosa started by inspecting the buccal mucosa on the intemal surface of the cheek, followed by the inspection of the buccal mucosa and its continuation or extensions up to the upper vestibular mucosa. The buccal mucosa was reflected sufficiently and inspected carefully for any mucosal changes in color and texture on both sides of the mouth. The gingiva and its extension to the alveolar mucosa were also inspected carefully for any mucosal changes in color and texture on both sides of the mouth. Cautious bimanual palpation of all mucosal surfaces was performed to examine the underlying structure and to find out if the patient felt any pain.

White lesion (leukoplakia) was defined as patches with a white coating that could not be removed and could not be defined as any other disease entity according to the current WHO definition [25]. Next to white, also red lesions were recorded Based on the profile, lesions were divided into flat, verrucous, and ulcerous. For each patient, the number of lesions was counted on the buccal and gingival mucosa, respectively. For the chewing and non-chewing side, the number of lesions were added, and the mean number was calculated over all smoking and non-smoking patients, respectively.

\section{Brush biopsies and exfoliative cytology}

Using a rigid nylon brush (e.g., ORCA-Btush, DGOD mbH, Leipzig, Gemany) capable of taking transepithehial, representative clls [26], at least two brush biopsies were taken from the chewing side as well as the opposite side yielding a total of four brush biopsies from each participant from four different anatomical areas. On either side of the mouth, one brush biopsy was taken from the buccal mucosa and one from the gingiva. The buccal part of the mouth refers to the intemal surface of the cheek, whereas the gingival region means the gingival mucosa and its extension to the alveolat mucosa. In the case of visible lesions, care was taken to obtain cells from those areas as well The brush was tumed at least ten times around its axis to collect cells from the lesion. The epithelial cells were transferred to a glass slide, immediately fixated with an alcohol-containing spray (Merckofix, Merck, Datmstadt, Gemany) to avoid desiccation. This procedure was repeated three or four times in order to collect a sufficient number of cells [26]. The slides were stained according to the method of Papanicolaou to be examined in a blinded fashion, so that the smoking status and other details of the participants were not known by the examiner. The following criteria were used [27]: (a) anisonucleosis, (b) hyperchromatic nuclei, (c) pleomorphism of cells, (d) increased nucleus/cytoplasm ratio, (e) atypical mitotic figures, and (f) no abnotmality seen. A slide is qualified as "abnotmal" when any criterion (a to e) is noted. We did not subdivide the grade of abnotmality in order to anticipate the histological grade of oral intraepithelial lesion (ONN).The number of cytological abnotmalities was summed up for the chewing and non-chewing side, respectively. Over all smoking and non-smoking patients, the mean number of cytological abnotmalities were calculated.

\section{Statistical analysis}

Statistical analyses were performed by using Excel software (Mictosoft Office, Seattle, USA) or the analytical software package STATA, version 12.0 (College Station, TX, USA). To measure the frequency of visible lesions (any mucosal change) and cytological changes (any change as defined above), we divided the number of participants with the respective characteristic through the number of participants for which this characteristic was assessed. These calculations were done separately for the four areas: buccal and gingival part of the chewing side as well as gingival and buccal part of the non-chewing side. This was done separately for nonsmokers and smokers. Because one side (chewing and nonchewing side, respectively) could have more than one visible lesion or cytological change, we also summed the number of visible lesions (and cytological changes) and averaged these by side over all participants. To assess the degree of agreement of visible inspection versus cytology, we calculated the interobserver agreement as the proportion of measurements where visible inspection and cytology agreed (for example, visible inspection: lesion present and cytology: abnormal), as well as kappa statistics [28]. Kappa statistics provide a measure for the degree of agreement taking in account the degree of agreement by chance alone. Values may be negative if agreement is worse than by chance; it is 0 if it is exactly as high as expected by chance and above 0 if it is higher than expected by chance. Values from 0.01 to 0.20 are considered as slight "agreement" and 0.21 to 0.40 as fair agreement. Compatison of two categorical variables was assessed by chi-square test; numerical variables were compared using the (non-parametric) MannWhitney $U$ test $p$ values of less than or equal to 0.05 were considered statistically significant.

\section{Results}

\section{Descriptive analysis of patient and measurement data}

Thirty non-smoking and 30 smoking chronic qat chewers were recruited for the study. Smoking participants had smoked for a mean of 17 yeats (tange, 5-50 yeats) and indicated to 
Clin Oral Invest

\begin{tabular}{|c|c|c|c|c|}
\hline Variable & Total $(N-60)$ & Smokers $(N-30)$ & Non-smokers $(N-30)$ & $p$ value \\
\hline \multicolumn{4}{|l|}{ Gender } & \multirow[t]{3}{*}{1.00} \\
\hline Male, $n(\%)$ & $56(93)$ & $28(93)$ & $28(93)$ & \\
\hline Fermale, $n(\%)$ & $4(7)$ & $2(7)$ & $2(7)$ & \\
\hline Age, median (IQB) & $35(25,53)$ & $35(25,52)$ & $34(25,55)$ & 0.84 \\
\hline \multicolumn{4}{|l|}{ Qat-chewing side } & \multirow[t]{3}{*}{0.02} \\
\hline Right, $n(\%)$ & $8(13)$ & $1(3)$ & $7(23)$ & \\
\hline Left, $n(\%)$ & $52(87)$ & $29(97)$ & $23(77)$ & \\
\hline Chewing years, median (IQB) & $15(10,32)$ & $15(10,29)$ & $17(10,33)$ & 0.60 \\
\hline Lifetime chewing hours, median (IQB) & $28,080(17,472,47,424)$ & $35,672(19,500,61,880)$ & $25,272(16,380,38,220)$ & 0.03 \\
\hline Alcohol consumption & 0 & 0 & 0 & 1.00 \\
\hline Qat type: Thamar & 60 & 30 & 30 & 1.00 \\
\hline Medication & 0 & 0 & 0 & 1.00 \\
\hline
\end{tabular}

$I Q B$ interquartile bounds

smoke a mean of 18 cigarettes a day (range, 10-60) using 3 different brands of cigarettes: Rothmans, Kamatan light, and Royals. In both groups, $93 \%$ of participants were male (Table 1). Most of the women have refused to participate due to society's culture. The median age among nonsmokers was 34 years and 35 years among smokets. In both groups, more participants preferred to chew on the right side, but the propottion of those chewing qat on the right side was significantly higher among non-smokers.

The results showed that visually only white (Fig. 1) or "white and red" but no purely red lesions were detected (Table 2). Overall, more than $90 \%$ were white lesions only. Because all visible lesions had white portions, they were lumped together as "white lesions." In terms of surface profile, all detected lesions were flat; none was verrucous or ulcerous. Visually, 116 of 240 regions ( $48 \%$ ) had white lesions. Exfoliative cytology detected an abnormality in 120 of 238 slides $(50 \%)$ as can be shown in Fig. 2, but did not in 118 $(50 \%)$. Two of 240 slides ( $1 \%$ ) could not be evaluated due to

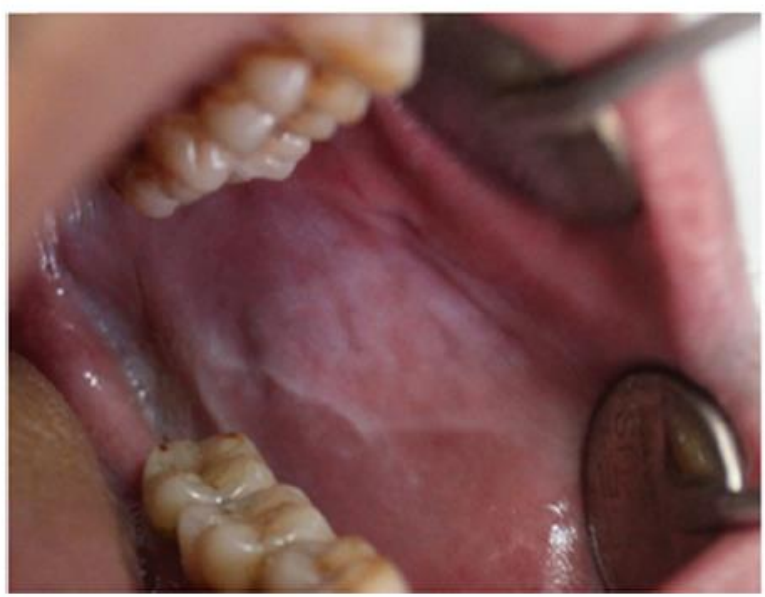

Fig. 1 White lesion in a non-smoker with 10-year qat chewing history low numbets of collected cells on the slides. All shides with any abnormality showed a combination of hyperchromatic nuclei, pleomorphism of cells, or an increased nucleus/ cytoplasm ratio. No slide showed anisonucleosis or atypical mitotic figures. Additionally, there was no abnormal cytological report based on one single abnormal criterion.

Analyzed by patient, $53(88 \%)$ and $50(83 \%)$ of all 60 participants had at least one (white) lesion or at least one cytological abnormality, respectively; 57 (95\%) had either and $46(77 \%)$ had both.

\section{Frequency of visible lesions and cytological changes among non-smokers in the four areas of the mouth}

Figure 3 depicts the proportion of non-smokers and smokers, respectively, with visible lesions (top) or cytological changes (bottom) in the four investigated regions of the mouth. Depending on the region, between 3 and $80 \%$ of non-smokers had visible lesions (Fig. 3, top). It was highest for the chewing side, and on either side it was higher on the buccal region than on the gingival region. In contrast, the proportion of nonsmokets with cytological changes tanged between $38 \%$ (buccal non-chewing side) and $73 \%$ (buccal chewing side; Fig. 3 , bottom). The cheek of the chewing side had the highest proportion of visible lesions as well as cytological changes.

\section{Frequency of visible lesions and cytological changes among smokers in four areas of the mouth}

Among smokers, the proportion of areas with visible lesions ranged between 23 and $93 \%$ (Fig. 3). Otherwise, the order of regions according to the proportion of smokers with visible lesions as well as those with cytological changes was similar to that among the nonsmokers; the only difference was that the gingival mucosa 
Table 2 Distribution of lesions by color and profile, respectively

\begin{tabular}{|c|c|c|c|c|}
\hline & \multicolumn{2}{|c|}{ Chewing side } & \multicolumn{2}{|c|}{ Non-chewing side } \\
\hline & $\begin{array}{l}\text { Buccal part } \\
(N-52)\end{array}$ & $\begin{array}{l}\text { Gingival part } \\
(N-32)\end{array}$ & $\begin{array}{l}\text { Buccal part } \\
(N-23)\end{array}$ & $\begin{array}{l}\text { Gingival part } \\
(N-9)\end{array}$ \\
\hline \multicolumn{5}{|l|}{ Lesions, color } \\
\hline White, $n(\%)$ & 49 (94) & $31(97)$ & $22(96)$ & $8(89)$ \\
\hline White and red, $n(\%)$ & $3(6)$ & $1(3)$ & $1(4)$ & $1(11)$ \\
\hline Red, $n$ & 0 & 0 & 0 & 0 \\
\hline \multicolumn{5}{|l|}{ Lesions, profile } \\
\hline Flat, $n(\%)$ & $52(100)$ & $32(100)$ & $23(100)$ & $9(100)$ \\
\hline Verrucous, $n$ & 0 & 0 & 0 & 0 \\
\hline Ulcerous, $n$ & 0 & 0 & 0 & 0 \\
\hline
\end{tabular}

White thick, white patches; white and red a mixed lesion of white and red; red an entirely red patch (erythroplakie); flat uniform flat; verrucous multiple keratotic plaques with rough surface projection; ulcerous showing induration, fissuring, and ulcer fomation on the non-chewing side had a higher proportion with visible lesions as well as cytological changes compared to e.g., the gingival mucosa on the chewing side. Again, the cheek of the chewing side was the region with the highest proportion of smokers with both visible lesions as well as cytological abnormalities.

\section{Comparison of visible lesions and cytological changes} between chewing side and non-chewing side as well as between non-smokers and smokers

The average of the sum of lesions on the chewing area (1.40) was significantly higher compared to the non-chewing area
Fig. 2 Percent of non-smokers (green dots) and smokers (yellow squares) with visible lesions (top) or with cytological changes

(bottom) in four regions of the mouth

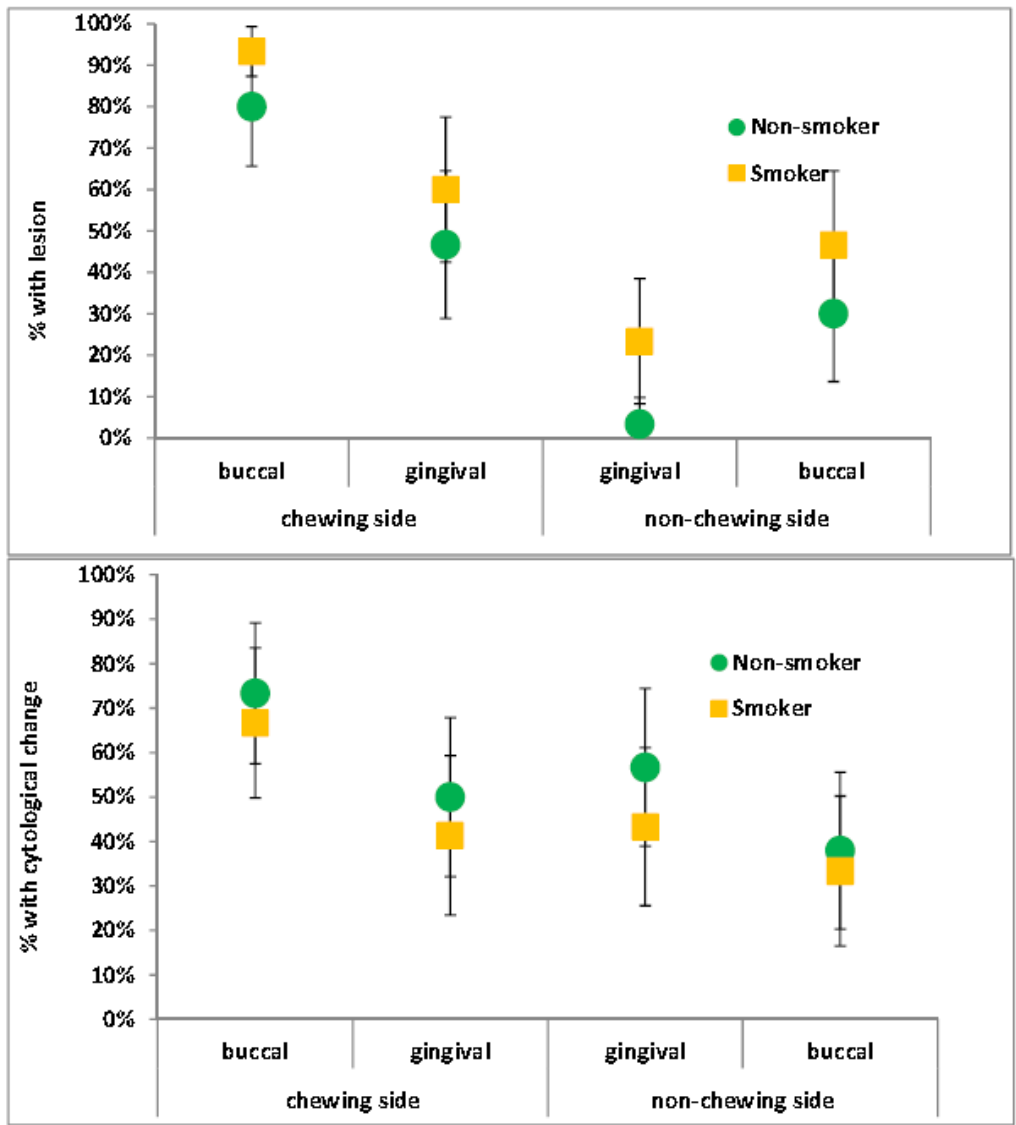




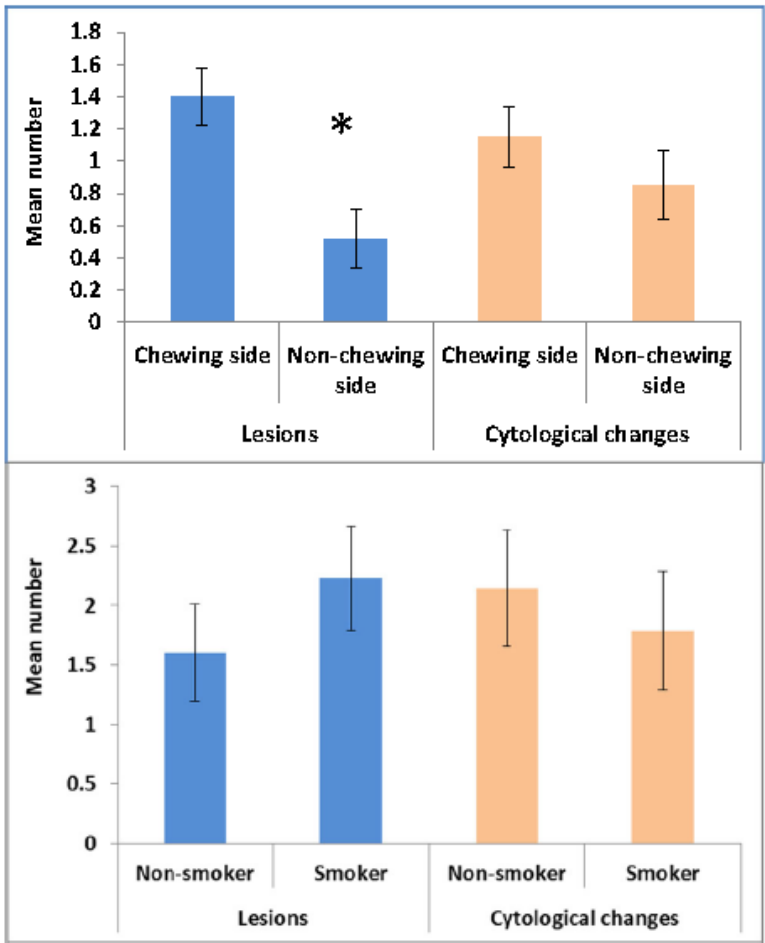

Fig. 3 Comparison of the mean number of lesions or cytological changes per participant, by chewing side (smokers and non-smokers pooled; top) and by smoking status (chewing side and non-chewing side pooled; bottom). Asterisk indicates significant difference

(0.52; $p$ value $<0.001$ ) (Fig. 3, top). The mean of the sum of cytological changes was also higher among the biopsies taken from the chewing side (1.15) than on the non-chewing side $(0.85)$, but the difference was not statistically significant.

Among non-smoking and smoking qat chewers, 83\% (25/30) and $93 \%(28 / 30)$, respectively, had white lesions $(p=0.23)$. Cytological changes were seen in $90 \%(27 / 30)$ of non-smokers and $77 \%(23 / 30)$ of smokers $(p=0.19)$. Comparison of the mean number of lesions or cytological changes per participant did not differ significantly by smoking status (Fig. 3, bottom). The pattem of the distribution of proportions of visible lesions and cytological changes, respectively, was very similar among non-smokers and smokers: in all anatomical regions, smokets (compared to non-smokers) had higher proportions of lesions (Fig. 3, top), but lower proportions of cytological changes (Fig. 3, bottom). However, $95 \%$ confidence intervals between non-smokers and smokets overlapped consistently indicating a lacking statistical significance.

\section{Degree of agreement of visible inspection and cytology}

Overall, the proportion of cytologically abnormal slides was only slightly higher among the shides taken from a white lesion compared to regions without ( 56 vs. $46 \% ; p=0.12$ ). The highest proportion of cytologically abnormal slides was found among those taken from white lesions at the buccal epithelium of the chewing side ( $75 \%(39 / 52)$ ) (Table 3$)$. Regarding the four different anatomical regions, the degree of agreement between visual inspection and histology ranged between 47 and $73 \%$. Kappa was overall 0.1 (slight agreement). In addition, it was 0.25 for the cheek of the chewing side (fair agreement), but below 0 for the other three regions, i.e., less than expected by chance.

Table 3 Cross-tabulation of results of visual inspection and exfoliative cytology, by anatomical site, as well as agrement and kappa statistics

\begin{tabular}{|c|c|c|c|c|c|c|c|c|}
\hline \multirow[t]{2}{*}{ Location } & \multirow[t]{2}{*}{ Lesion visible } & \multicolumn{5}{|c|}{ Exfoliative cytology } & \multirow[t]{2}{*}{ Agreement } & \multirow[t]{2}{*}{ Kappa } \\
\hline & & Abnomal & $\%$ & Not abnomal & $\%$ & Total & & \\
\hline \multirow[t]{3}{*}{ Chewing area, buccal } & Yes & 39 & 75 & 13 & 25 & 52 & \multirow[t]{3}{*}{0.73} & \multirow[t]{3}{*}{0.25} \\
\hline & No & 3 & 38 & 5 & 63 & 8 & & \\
\hline & Total & 42 & 70 & 18 & 30 & 60 & & \\
\hline \multirow[t]{3}{*}{ Chewing area, gingival } & Yes & 14 & 44 & 18 & 56 & 32 & \multirow[t]{3}{*}{0.47} & \multirow[t]{3}{*}{$<0$} \\
\hline & No & 13 & 48 & 14 & 52 & 27 & & \\
\hline & Total & 27 & 46 & 32 & 54 & 59 & & \\
\hline \multirow[t]{3}{*}{ Non-chewing area, gingival } & Yes & 3 & 38 & 5 & 63 & 8 & \multirow[t]{3}{*}{0.47} & \multirow[t]{3}{*}{$<0$} \\
\hline & No & 27 & 52 & 25 & 48 & 52 & & \\
\hline & Total & 30 & 50 & 30 & 50 & 60 & & \\
\hline \multirow[t]{3}{*}{ Non-chewing area, buccal } & Yes & 8 & 35 & 15 & 65 & 23 & \multirow[t]{3}{*}{0.53} & \multirow[t]{3}{*}{$<0$} \\
\hline & No & 13 & 36 & 23 & 64 & 36 & & \\
\hline & Total & 21 & 36 & 38 & 64 & 59 & & \\
\hline \multirow[t]{3}{*}{ Overall } & Yes & 64 & 55.7 & 51 & 44 & 115 & \multirow[t]{3}{*}{0.55} & \multirow[t]{3}{*}{0.1} \\
\hline & No & 56 & 45.5 & 67 & 54 & 123 & & \\
\hline & Total & 120 & 50.4 & 118 & 50 & 238 & & \\
\hline
\end{tabular}




\section{Discussion}

This study examined the influence of chewing qat among nonsmokers and smokers in four anatomical regions of the mouth. Overall at least $77 \%$ of study participants had at least one visible (white) lesion or cytological abnormality. Among all four anatomical regions, the buccal part of the chewing side had the highest proportion of white lesions and also the highest proportion of cytological abnormalities, both in nonsmokers and smokers. No significant differences were found between non-smokers and smokers. The chewing side had a significantly higher proportion of white lesions, but a nonsignificantly higher proportion of cytological changes. The degree of interobserver agreement (kappa value) between visual inspection and cytological examination was at best fait.

We found a very high overall frequency of mucosal changes among all qat chewers. This might be in part due to the study entry requirement of having chewed for at least 5 yeats and a minimum of 3 days a week Our results compate well with those from Schmidt-Westhausen [29] as well as Gorsky [11]. Schmidt-Westhausen et al. reported that $75 \%$ of Yemeni women who chewed qat habitually for at least 5 years had white lesions on the chewing side (vs. $6 \%$ on the opposite side). Gorski et al found that $83 \%$ of persons chewing qat for at least 3 yeats had white lesions (compared with only $16 \%$ among non-chewers). However, it contrasts for example to the study by Ali et al. [12], who examined Yemenites having chewed qat for at least 10 years and found white lesions in 5 ( $23 \%$ ) of 22 individuals ( 11 smoking, 11 non-smoking) only. Reasons for these differences are unclear, but may theoretically be related to differences of effects by type of qat, an unknown selection bias, confounder, or due to chance.

We investigated in detail how increasing distance from the buccal mucosa on the chewing side impacts the prevalence of mucosal changes in other parts of the mouth. The results did not show a clear trend as a function of distance, in regard neither to white lesions nor cytological changes and regardless of smoking status. Nevertheless, the proportion of lesions or cytological changes was higher on the chewing side, and on that side, it was consistently highest on the buccal part. This suggests that it is the buccal part of the side where the patient has chewed qat is the most affected, pethaps mainly due to friction. It is surprising that the proportion of white lesions and of cytological changes is still high on the non-chewing side, this may be due to the fact that persons who indicate that they chew only on one side sometimes also chew unknowingly on the other side as well. Another explanation might be that chemicals of the leaves or chemical additives lead to mucosal changes in all areas of the mouth $[1,11]$.

In this study, smoking did not make any differences as a potential risk factor for the prevalence of mucosal changes. This is in agreement with the study by Schmidt-Westhausen et al [29] and Gorsky et al. [11], but in contrast to another study published by Ali et al. in 2007 [12]. In the latter report, white lesions were observed in $36 \%$ (4/11) on the chewing side of smokers and in $9 \%(1 / 11)$ of qat-chewing nonsmokers. Schmidt-Westhausen had investigated the frequency of white lesions among Yemeni women and reported that the frequency of white lesions was significantly correlated with the duration of qat chewing, but not with the duration of smoking [29]. Gorsky et al. found a prevalence of white lesions among $84 \%$ of smoking qat chewers and $80 \%$ of nonsmoking qat chewers ( $p$ value for difference $>0.05$ ), but only $20 \%$ of smoking non-chewers and $13 \%$ of non-smoking nonchewers [11]. Gorsky et al. concluded that this finding "supports a direct association between oral white mucosal plaques and khat chewing."

Among all slides taken, the probability to find cytological changes was about $50 \%$, but it differed hatdly between the areas where the specimens were taken from showed white lesions ( $56 \%$ ) or not $(46 \%)$. The only exception was white lesions at the buccal epithelium of the chewing side; the agreement reached $73 \%$ with a kappa value of 0.25 .

The high proportion of cytologically altered specimens from seemingly inconspicuous areas may be surprising. However, it is known that cytopathological changes may be present in areas in which there is no chinical evidence of an oral lesion on visual examination alone [30]. In the study reported by Christian, 7 ( $8 \%$ ) oral brush biopsy results taken from 93 visible lesions were classified as "abnormal" (six as "atypical" (with "epithelial changes of uncertain diagnostic significance"), one as frankly "dysplastic") [31]. Three of the six individuals with atypical findings underwent scalpel biopsy and showed dysplasia in two (33\%) and had a benign diagnosis in one; the one brush biopsy result that was "positive" for dysplasia was later confirmed by scalpel biopsy to be dysplastic, resulting in an overall percentage of 3 dysplastic samples (3\%) among 93 visible lesions. These data highlight how sensitivity of oral brush biopsies would drop if cleat-cut dysplasia is taken as threshold for positive cases.

From this kind of data, the prevalence of oral dysplasia among Yemenite men can be roughly estimated. Chewing qat is extremely frequent and reaches $90 \%$ among men [32], the prevalence of any visible lesion among qat chewers was $88 \%$, the proportion of abnormal cytological results among visible lesions was $56 \%$ (Table 3 ), and the probability of a dysplasia among brush biopsies classified as "abnormal" is $33 \%$ [31]; the prevalence of male Yemenites with oral dysplastic changes can be estimated conservatively as

$90 \% \times 88 \% \times 56 \% \times 33 \%=15 \%$

Moreover, the clinical management of chronic qat chewers with lesions who ate unwilling to give up chewing qat remains a challenge. In countries like Yemen, the prevalence of the habit and the prevalence of both visible lesions and cytological abnormalities are so high that a regular short-term followup is unrealistic. However, even the exact role of qat on the 
oral mucosa remains unclear and demands further research. For example, the effect of qat on the oral mucosa may be purely mechanical inducing frictional keratosis. On the other hand, recent in vitro studies have found that qat induces apoptotic cell death [33] and modulates the cell cycle [34] giving rise to the hypothesis that these effects may act also in vivo facilitating malignant transformations. Thus, although epidemiological data suggest a role of qat for the high oral cancer death rate, further, both experimental/laboratory as well as epidemiological reseatch is needed to clatify this link with certainty. Since the oral cancer mortality among women is particularly high in Yemen [3] and qat chewing is not as prevalent as among men [35], epidemiological studies among women may give important clues on the potentially causal role of qat for oral cancer.

\section{Conclusion}

In conclusion, chewing qat is associated with a high prevalence of both white lesions and cytological changes, particulatly on the chewing side. The underlying mechanism likely involves both frictional as well as others, such as chemical factors. The proportions of samples demonstrating abnormalities were very similat among smokers and non-smokers in all four regions no matter if just detected by inspection or cytology. The fact that visual inspection was at best fair predictor for cytological changes and that many cytological changes occur at regions where no lesions were visible complicates clinical management of chronic qat chewers. Thus, the clinical management should still be based on the presence or absence of dysplasia and the degree of dysplasia. Future studies have to show that oral brush biopsies including adjuvant techniques (e.g., DNA cytometry) may be suitable as a screening tool in the clinical setting.

Conflict of interest Professor Torsten W. Remmerbach is the CEO of the DGOD mbH, Leipzig, Germany (dental healthcare supplier). All other authors: none declared.

\section{References}

1. Ali AA, Al-Sharabi AK, Aguime JM, Nahas R (2004) A study of 342 oral keratotic white lesions induced by qat chewing among 2500 Yemeni. J Oral Pathol Med Off Publ Int Assoc Oral Pathol Am Acad Oral Pathol 33(6):368 372

2. Ali AA, Al-Sharabi AK, Aguine JM (2006) Histopathological changes in oral mucosa due to takhzeen al-qat: a study of 70 biopsies. J Oral Pathol Med Off Publ Int Assoc Oral Pathol Am Acad Oral Pathol 35(2):81 85

3. IARC. Globocan database 2008. Accessed on: 09 August 2013; available at: globocaniara.fi. 2008
4. Al-Hebshi NN, Skaug N (2005) Khat (Catha edulis) an updated review. Addict Biol 10(4):299 307

5. Al-Habori M(2005) The potential adverse effects of habitual use of Catha edulis (khat). Expert Opin Drug Saf 4(6):1145 1154

6. al-Meshal IA, Qureshi S, Ageel AM, Tarig M. The toxicity of Catha edulis (khat) in mice. J Subst Abus 1991;3(1):107 115

7. Macigo FG, Mwaniki DL, Guthua SW (1995) The association between oral leukoplakia and use of tobacco, alcohol and khat based on relative risks assessment in Kenya Eur J Oral Sci 103(5):268 273

8. Hill CM, Gibson A (1987) The oral and dental effects of q'at chewing. Oral Surg Oral Med Oral Pathol 63(4):433 436

9. Yarom N, Epstein J, Levi H, Porat D, Kaufman E, Gorsky M. Oral manifestations of habitual khat chewing a case-control study. Oral Surg Oral Med Oral Pathol Oral Radiol Endod 2010;109(6): 6006

10. El-Wajeh YAM, Thornhill MH (2009) Qat and its health effects. Br Dent J 206(1):17 21

11. Gorsky M, Epstein B, Levi H, Yarom N (2004) Oral white lesions associated with chewing khat. Tob Induc Dis 2(3):145 150

12. Ali AA (2007) Histopathologic changes in oral mucosa of Yemenis addicted to water-pipe and cigarette smoking in addition to takhzeen al-qat. Oral Surg Oral Med Oral Pathol Oral Radiol Endod 103(3): 55 e59

13. Ahmed HGE, Omer ASA, Abd Algaffar SA (2011) Cytological study of exfoliative buccal mucosal cells of qat chewers in Yemen. Diagn Cytopathol 39(11):796 800

14. Halboub ES, Abdulhug M, Al-Mandili A (2012) Oral and pharyngeal cancers in Yement a retrospective study. East Mediten Health J Rev Santé Méditerranée Orient Al-Majallăh Al-Șił̣inyyah Li-Sharq Al-Mutawassit 18(9):985 991

15. Rodriguez T, Altieri A, Chatenoud L, et al. (2004) Risk factors for oral and pharyngeal cancer in young adults. Oral Oncol 40(2):207 213

16. Nasr $\mathrm{AH}$, Khatri ML (2000) Head and neck squamous cell carcinoma in Hajjah, Yemen Saudi Med J 21(6):565 568

1\%. Schentele C, Nassar A, kenchart $P A$ (ZUU/) Hrevalence ot oral cancer and potentially malignant lesions among shammah users in Yemen. Oral Oncol 43(1):42 50

18. Hullmann M, Reichert TE, Dahse R, et al. [Oral cytology: historica] development, current status, and perspectives]. Mund- KieferGesichtschirurgie MKG 2007;11(1):1 9

19. Driemel 0 , Dahse R, Hakim SG, et al. (2007) Laminin-5 immunocytochernistry: a new tool for identifying dysplastic cells in oral brush biopsies. Cytopathol off J Br Soc Clin Cytol 18(6):348 355

20. Driemel O, Dahse R, Bemdt A, et al. (2007) High-molecular tenascin-C as an indicator of atypical cells in oral brush biopsies. Clin Oral Investig 11(1):93 99

21. Potter TJ, Summerlin D-J, Campbell JH (2003) Oral malignancies associated with negative transepithelial brush biopsy. J Oral Maxillofac Surg off J Am Assoc Oral Maxillofac Surg 61(6): 674677

22. Remmerbach $\mathrm{TW}$, Weidenbach $\mathrm{H}$, Pomjanski $\mathrm{N}$, et al. (2001) Cytologic and DNA-cytometric early diagnosis of oral cancer. Anal Cell Pathol J Eur Soc Anal Cell Pathol 22(4):211 221

23. Remmerbach TW, Mathes SN, Weidenbach H, Hemprich A Böcking A (2004) Noninvasive brush biopsy as an innovative tool for early detection of oral carcinomas. Mund- KieferGesichtschirurgie MKG 8(4):229 236

24. WMA Declaration of Helsinki ethical principles for medical research involving human subjects. Accessed on: 14 December 2013; available at: Www wmant/en/30publications/10policies/b3/

25. Warnakulasuriya S, Johnson NW, van der Waal I (2007) Nomenclature and classification of potentially malignant disorders of the oral mucosa. J Oral Pathol Med Off Publ Int Assoc Oral Pathol Am Acad Oral Pathol 36(10):575 580 
26. Remmerbach $\mathrm{T}$ (2010) Früherkennung rettet Leben. Oralchirurgie J $3: 1417$

27. Ebhardt H, Schmidt-Westhausen A (2010) Die Leukoplakie der Mundschleimhaut: Diagnostik - Therapie - Prognose. Oralchirungie J 3:6 11

28. Wikipedia. Cohens kappa. [cited 2014 ot 20]; Available from: http://de.wikipedia.org/wiki/Cohens Kappa

29. Schmidt-Westhausen A, Al Sanabani J, Al-Sharabi A (2014) Prevalence of oral white lesions due to qat chewing among women in Yemen. Oral Dis 20(7):675 681

30. Patton LL, Epstein JB, Ken AR (2008) Adjunctive techniques for oral cancer examination and lesion diagnosis: a systematic review of the literature. J Am Dent Assoc 139(7):896 905 quiz 9934

31. Christian DC (2002) Computer-assisted analysis of oral brush biopsies at an oral cancer screening program. J Am Dent Assoc 133(3):357 362
32. Laswar AKN, Dar wish $H$ (2009) Prevalence of cigarette smoking and khat chewing among Aden university medical students and their relationship to BP and body mass index. Saudi J Kidney Dis Transplant Off Publ Saudi Cent Organ Transplant Saudi Arab 20(5):862 866

33. Lukandu OM, Coster DE, Neppelberg E, Johannessen AC, Vintermyr OK (2008) Khat (Catha edulis) induces reactive oxygen species and apoptosis in nomal human oral keratinocytes and fibroblasts. Toxicol Sci Off J Soc Toxicol 103(2):311 324

34. Lukandu OM, Costea DE, Dimba EA, et al. (2008) Khat induces G1-phase arrest and increased expression of stress-sensitive $\mathrm{p}^{53}$ and p16 proteins in nomal human oral keratinocytes and fibroblasts: cell cycle anest and 53 induction by khat. Eur J Oral Sci 116(1): $23 \quad 30$

35. Ageely HM (2009) Prevalence of khat chewing in college and secondary (high) school students of Jazan region, Saudi Arabia. Harm Reduct J 6:11 
Erratum zu: Clinical and cytological study of the oral mucosa of smoking and non-smoking qat chewers in Yemen.

Authors: Hijazi M1, Jentsch H, Al-Sanabani J, Tawfik M, Remmerbach TW.

Publiziert online: 29. August 2015

c) Springer-Verlag Berlin Heidelberg 2015.

Die veröffentlichte Version des Artikels enthält die folgenden Fehler:

Seite 18, zweiter Absatz, zweite Zeile von unten: die Referenz auf "Abbildung 2" sollte entfernt werden.

Seite 18, rechte Spalte, Absatz "Frequency of visble lesions... among non-smokers...", sollte hinweisen auf Abbildung 2, nicht Abbildung 3.

Seite 18, rechte Spalte, Absatz "Frequency of visble lesions... among smokers...", sollte hinweisen auf Abbildung 2, nicht Abbildung 3.

Außerdem befindet sich ein Fehler auf Seite 21, rechte Spalte, siebte Zeile von unten. Der Text mit den Worten "... and the probability of a dysplasia among brush biopsies classified as "abnormal" is 33\% [31], the prevalence of male Yemenites with oral dysplastic changes can be estimated conservatively as: $90 \%{ }^{*} 88 \%{ }^{*} 56 \%{ }^{*} 33 \%=15 \%$." sollte stattdessen folgendermaßen formuliert sein: "and the probability of a dysplasia among brush biopsies classified as "abnormal" is at least $43 \%$ [31], the prevalence of male Yemenites with oral dysplastic changes can be estimated conservatively as: $90 \%{ }^{*} 88 \%{ }^{*} 56 \%{ }^{*} 43 \%=19 \%$." 


\section{Zusammenfassung}

Dissertation zur Erlangung des akademischen Grades Dr. med. dent.

Clinical and cytological study of the oral mucosa of smoking and non-smoking qat chewers in Yemen

Eingereicht von:

Mohammed Hijazi

Angefertigt am:

Universitätsklinikum Leipzig AöR, Department für Kopf- und Zahnmedizin, Poliklinik für Zahnerhaltung und Parodontologie, Funktionsbereich Parodontologie

Betreut von:

Univ.-Prof. Dr. med. habil. Dr. h.c. Holger Jentsch

Univ.-Prof. Dr. med. dent. habil. Torsten W. Remmerbach

November 2016

Die Studie wurde durchgeführt, um die mögliche Rolle von Qat und Zigarettenrauchen in der Prävalenz sichtbarer bzw. zytologisch nachweisbarer Veränderungen in der Mundschleimhaut bei Jemeniten zu untersuchen.

Wir rekrutierten 30 nicht-rauchende und 30 rauchende, nur auf einer Seite und seit mindestens 5 Jahren Qat-kauende Jemeniten. Patienten mit anderen Gewohnheiten, die diese Assoziation verzerren könnten, wurden ausgeschlossen. Wir inspizierten die Mundhöhle auf das Vorliegen von Läsionen und nahmen Bürstenbiopsien von der bukkalen Mukosa und Gingiva der Kauseite, aber auch der kontralateralen. 
Alle sichtbaren Läsionen waren flach und homogen, zytologische Veränderungen wurden häufig entdeckt. Bei $77 \%$ aller 60 Teilnehmer wurden weiße Läsionen und gleichzeitig zytologische Veränderungen entdeckt. Auf der Kauseite variierte der Anteil mit weißen Läsionen - in Abhängigkeit von der anatomischen Region und dem Raucherstatus zwischen $47 \%$ und $93 \%$. Dies war statistisch signifikant häufiger als auf der kontralateralen (Nicht-Kau-) Seite (3\% - 47\%). Der Anteil der untersuchten Regionen mit Abnormalitäten war bei Rauchern und Nicht-Rauchern ähnlich. Die kappa-Statistik bezüglich der Übereinstimmung von Inspektion und Zytologie war niedrig.

Die hohe Prävalenz sichtbarer Läsionen und zytologischer Abnormalitäten unter QatKonsumenten war unabhängig vom Raucherstatus. Die moderate Übereinstimmung zwischen Inspektion und Zytologie demonstriert, wie schwierig das klinische Management chronischer Qat-Konsumenten ist. Bürstenbiopsien könnten zukünftig im diagnostischen Vorgehen von Nutzen sein. 


\section{Literaturverzeichnis}

1. IARC. Globocan database 2008. Accessed on: 09 August 2013; available at: globocan.iarc.fr. 2008.

2. Ali AA, Al-Sharabi AK, Aguirre JM, Nahas R. A study of 342 oral keratotic white lesions induced by qat chewing among 2500 Yemeni. J Oral Pathol Med Off Publ Int Assoc Oral Pathol Am Acad Oral Pathol. 2004;33: 368-372. doi:10.1111/j.1600-0714.2004.00145.x

3. Ali AA. Histopathologic changes in oral mucosa of Yemenis addicted to water-pipe and cigarette smoking in addition to takhzeen al-qat. Oral Surg Oral Med Oral Pathol Oral Radiol Endod. 2007;103: e55-59. doi:10.1016/j.tripleo.2006.10.008

4. Ali AA, Al-Sharabi AK, Aguirre JM. Histopathological changes in oral mucosa due to takhzeen al-qat: a study of 70 biopsies. J Oral Pathol Med Off Publ Int Assoc Oral Pathol Am Acad Oral Pathol. 2006;35: 81-85. doi:10.1111/j.1600-0714.2006.00362.x

5. al-Meshal IA, Qureshi S, Ageel AM, Tariq M. The toxicity of Catha edulis (khat) in mice. J Subst Abuse. 1991;3: 107-115.

6. Macigo FG, Mwaniki DL, Guthua SW. The association between oral leukoplakia and use of tobacco, alcohol and khat based on relative risks assessment in Kenya. Eur $\mathrm{J}$ Oral Sci. 1995;103: 268-273.

7. Hill CM, Gibson A. The oral and dental effects of q'at chewing. Oral Surg Oral Med Oral Pathol. 1987;63: 433-436.

8. Yarom N, Epstein J, Levi H, Porat D, Kaufman E, Gorsky M. Oral manifestations of habitual khat chewing: a case-control study. Oral Surg Oral Med Oral Pathol Oral Radiol Endod. 2010;109: e60-66. doi:10.1016/j.tripleo.2010.02.022

9. EI-Wajeh YAM, Thornhill MH. Qat and its health effects. Br Dent J. 2009;206: 17-21. doi:10.1038/sj.bdj.2008.1122

10. Gorsky M, Epstein JB, Levi H, Yarom N. Oral white lesions associated with chewing khat. Tob Induc Dis. 2004;2: 145-150. doi:10.1186/1617-9625-2-3-145 
11. Ahmed HGE, Omer ASA, Abd Algaffar SA. Cytological study of exfoliative buccal mucosal cells of Qat chewers in Yemen. Diagn Cytopathol. 2011;39: 796-800. doi:10.1002/dc.21462

12. Halboub ES, Abdulhuq M, AI-Mandili A. Oral and pharyngeal cancers in Yemen: a retrospective study. East Mediterr Health J Rev Santé Méditerranée Orient Al-Majallah Al-Ṣiḥḥiyah Li-Sharq Al-Mutawassiṭ. 2012;18: 985-991.

13. Rodriguez T, Altieri A, Chatenoud L, Gallus S, Bosetti C, Negri E, et al. Risk factors for oral and pharyngeal cancer in young adults. Oral Oncol. 2004;40: 207-213.

14. Nasr AH, Khatri ML. Head and neck squamous cell carcinoma in Hajjah, Yemen. Saudi Med J. 2000;21: 565-568.

15. Scheifele C, Nassar A, Reichart PA. Prevalence of oral cancer and potentially malignant lesions among shammah users in Yemen. Oral Oncol. 2007;43: 42-50. doi:10.1016/j.oraloncology.2005.12.028

16. Hullmann M, Reichert TE, Dahse R, von Eggeling F, Pistner $H$, Kosmehl $H$, et al. [Oral cytology: historical development, current status, and perspectives]. Mund- KieferGesichtschirurgie MKG. 2007;11: 1-9. doi:10.1007/s10006-006-0041-5

17. Papanicolaou GN. A New procedure for staining vaginal smears. Science. 1942;95: 438-439. doi:10.1126/science.95.2469.438

18. Schneider G. Krebserkennung und Zytodiagnostik. Dtsch Zahnarztl Z. 1952;7: 11271143.

19. Sandler HC, Stahl SS, Cahn LR, Freund HR. Exfoliative cytology for detection of early mouth cancer. Oral Surg Oral Med Oral Pathol. 1960;13: 994-1009.

20. Sandler HC. Cytological screening for early mouth cancer. Cancer. 1962;15: 11191124.

21. Driemel O, Dahse R, Hakim SG, Tsioutsias T, Pistner H, Reichert TE, et al. Laminin5 immunocytochemistry: a new tool for identifying dysplastic cells in oral brush biopsies. Cytopathol Off J Br Soc Clin Cytol. 2007;18: 348-355. doi:10.1111/j.13652303.2006.00401.x 
22. Driemel O, Dahse R, Berndt A, Pistner H, Hakim SG, Zardi L, et al. High-molecular tenascin-C as an indicator of atypical cells in oral brush biopsies. Clin Oral Investig. 2007;11: 93-99. doi:10.1007/s00784-006-0086-8

23. Potter TJ, Summerlin D-J, Campbell JH. Oral malignancies associated with negative transepithelial brush biopsy. J Oral Maxillofac Surg Off J Am Assoc Oral Maxillofac Surg. 2003;61: 674-677. doi:10.1053/joms.2003.50136

24. Remmerbach TW, Weidenbach H, Pomjanski N, Knops K, Mathes S, Hemprich A, et al. Cytologic and DNA-cytometric early diagnosis of oral cancer. Anal Cell Pathol J Eur Soc Anal Cell Pathol. 2001;22: 211-221.

25. Remmerbach TW, Mathes SN, Weidenbach $\mathrm{H}$, Hemprich A, Böcking A. [Noninvasive brush biopsy as an innovative tool for early detection of oral carcinomas]. Mund- KieferGesichtschirurgie MKG. 2004;8: 229-236. doi:10.1007/s10006-004-0542-z 


\section{Anlagen}

\subsection{Darstellung des eigenen Beitrags}

Ich habe die folgenden, eigenen, wissenschaftlichen Beiträge für die Arbeit geleistet:

- Idee und Konzeption der Arbeit

- Erarbeitung der Studieninstrumente (Fragebogen, Erhebungsinstrument)

- Praktische Durchführung der Studie im Jemen

- Auswertung der Daten

- Abfassen der Ergebnisse in einem wissenschaftlichen Artikel

\subsection{Selbstständigkeitserklärung}

Erklärung über die eigenständige Abfassung der Arbeit

Hiermit erkläre ich, dass ich die vorliegende Arbeit selbständig und ohne unzulässige Hilfe oder Benutzung anderer als der angegebenen Hilfsmittel angefertigt habe. Ich versichere, dass Dritte von mir weder unmittelbar noch mittelbar geldwerte Leistungen für Arbeiten erhalten haben, die im Zusammenhang mit dem Inhalt der vorgelegten Dissertation stehen, und dass die vorgelegte Arbeit weder im Inland noch im Ausland in gleicher oder ähnlicher Form einer anderen Prüfungsbehörde zum Zweck einer Promotion oder eines anderen Prüfungsverfahrens vorgelegt wurde. Jedes aus anderen Quellen und von anderen Personen übernommene Material, das in der Arbeit verwendet wurde oder auf das direkt Bezug genommen wird, wurde als solches kenntlich gemacht. Insbesondere wurden alle Personen genannt, die direkt an der Entstehung der vorliegenden Arbeit beteiligt waren. Die aktuellen gesetzlichen Vorgaben in Bezug auf die Zulassung der klinischen Studien, die Bestimmungen des Tierschutzgesetzes, die Bestimmungen des Gentechnikgesetzes und die allgemeinen Datenschutzbestimmungen wurden eingehalten. Ich versichere, dass ich die Regelungen der Satzung der Universität Leipzig zur Sicherung guter wissenschaftlicher Praxis kenne und eingehalten habe. 


\subsection{Lebenslauf}

15.10.2011

07.09 .2010

\section{Berufserfahrung}

29.11.2006

01.10 .2006

$-01.10 .2010$

01.10 .2010

01.07.03 bis 02.09 .06

03.03.03 bis 06.06 .03

10/1998-12/1999
Mohammed Hijazi

Mescheder Weg 45

13507 Berlin

004917641378310

mythijazi@yahoo.de

Geb. am 09. Februar 1971

in Khan Younis Gaza

Deutsch

Verheiratet, drei Kinder

Master of Oral Medicine in Implantology

Erteilung der Approbation als Zahnarzt

Anerkennung als Fachzahnarzt für Oralchirurgie

Entlasstungsassistent bei Frau Dr. Sabine Wintersperger, Wiesenpromenade 7, 12587 Berlin

Niedergelassener Zahnarzt, Berliner Straße 25, 13507 Berlin

Weiterbildungsassistent auf dem Gebiet der Oralchirurgie bei Univ.-Prof. Dr. Dr. mult. h.c. Jürgen Bier

Abteilung für Mund-, Kiefer-, Gesichtschirurgie der

Humboldt- Universität zu Berlin

Tätigkeit als Gastarzt bei Prof.

Dr. Dr. Dr. h.c. K. Wangerin

Klinik für Mund, Kiefer und Gesichtschirurgie

Marienhospital Stuttgart

Tätigkeit als Zahnarzt im Modern Dental Centre in Sudan 
Hochschule

1993-1998

Schulbildung

1977-1990

Sprachen

Berlin, 03.11.2016
Studium der Zahnheilkunde an der Universität Khartoum / Sudan, Abschluss: Bachelor of Dental Surgery (B.D.S.)

Gymnasium in Khan Younis Gaza in Palästina

Arabisch (Muttersprache)

Deutsch (sehr gut)

Englisch (sehr gut) 


\subsection{Danksagung}

Mein besonderer Dank gilt meinem Doktorvater Herr Professor Dr. Dr. h.c. Holger Jentsch, der mir die Möglichkeit gab dieses Promotionsarbeit zu realisieren, der mir als Ideen- und Ratgeber währenddessen stets zur Verfügung stand und dem ich viel zu verdanken habe.

Mein weiterer Dank gilt meinem Betreuer Herrn Professor Dr. Torsten W. Remmerbach, für die freundliche und weitreichende Betreuung sowohl bei den Vorbereitungen als auch bei der Durchführung meiner Arbeit.

Meiner Frau danke ich von ganzem Herzen für ihre unermüdliche Unterstützung, ihre Liebe und Motivation. 